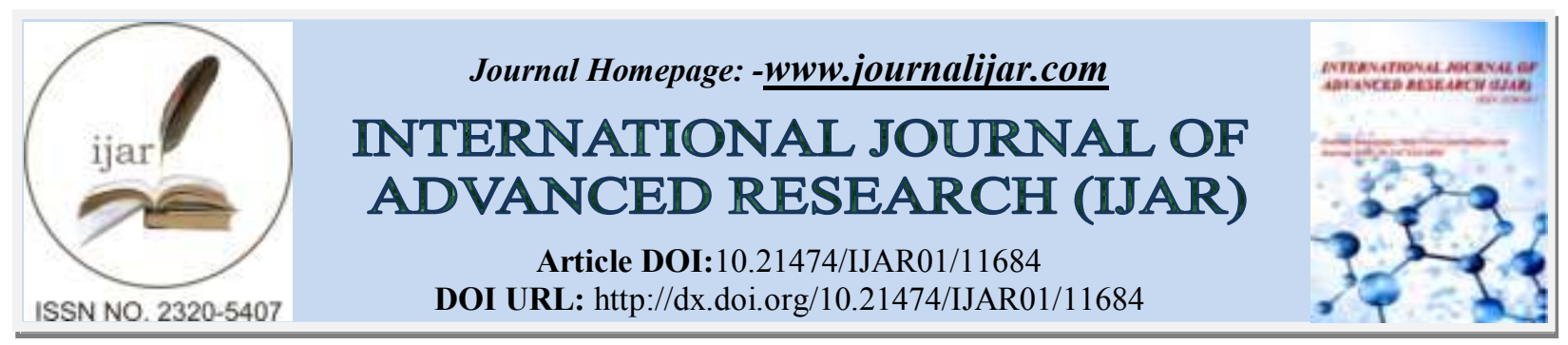

RESEARCH ARTICLE

\title{
QUALITATIVE PHYTOCHEMICAL SCREENING OF SELECTED MEDICINAL PLANTS OF DAKSHINA KANNADA DISTRICT
}

\author{
Laveena K.B and Chandra $M$ \\ Department of Postgraduate Studies and Research in Biosciences, Mangalore University, Mangalagangothri - 574 \\ 199, Mangalore, India.
}

\section{Manuscript Info \\ Manuscript History \\ Received: 10 July 2020 \\ Final Accepted: 14 August 2020 \\ Published: September 2020}

\section{Key words:-}

Bioactive Compounds, Medicinal Plants, Phytochemical, Primary Metabolites, Secondary Metabolites

\section{Abstract}

Purpose: The aim this research was to evaluate the phytochemical profiles of leaf extracts of selected medicinal plants viz., Alternanthera ficoidea L., Mussaenda belilla L., Carica papaya L., Talinum fruticosum L., Kalanchoe pinnata L., and Eupatorium perfoliatum L.

Methods: Plants which were collected was extracted using three solvents aqueous, ethanol and methanol and phytochemical analysis was carried out for the leaf extracts as per the standard methods.

Results: The leaf extracts of selected medicinal plants showed the presence of carbohydrates, proteins, amino acids, alkaloids, saponins, phenols, phytosterols, tannins, glycosides, steroids, terpenoids and flavonoids in three different solvents.

Conculsion: Different solvent extraction played important role in detection phytochemicals in different selected leaf samples. Methanol can extract most of the compounds like in water or ethanol. Methanol is the best solvent for detection of secondary metabolites. Therefore, methanol extract can be used to evaluate the activity of medicinal plants.

Copy Right, IJAR, 2020,. All rights reserved.

\section{Introduction:-}

The employment of medicinal plants for the cure of many diseases is related to folk medicine from different parts of the world. Natural products from some plants, fungi, bacteria and other organisms continue to be used in pharmaceutical preparations either as pure compounds or as extracts. There is an enormous diversity of compounds that can be isolated and elucidated from plants (1). Plant synthesizes a wide range of chemical compounds which are classified based on their chemical class, biosynthetic origin and functional groups into primary and secondary metabolites. Primary metabolites directly involved in growth and development while secondary metabolites are not involved directly and they have been worked as biocatalysts. Primary metabolites are widely distributed in nature, occurring in one form or another in virtually all organisms. They are like chlorophyll, amino acids, nucleotides, carbohydrates etc., which have a key role in metabolic processes such as photosynthesis, respiration and nutrient assimilation. They are used as industrial raw materials and food additives (2).

Phytochemicals are defined as bioactive non-nutrient plant compounds in fruits, vegetables, grains, and other plant foods that have been linked to reducing the risk of major chronic diseases. The word 'phyto-' is derived from the Greek phyto which means - plant (3). The presence of these bioactive components are said to confer them with 
resistance against bacterial, fungal and pesticidal pathogens. These bioactive components are said to be responsible for the antimicrobial effects of plant extracts in vitro $(4,5)$. Phytoconstituents are the natural bioactive compounds found in plants. These phytoconstituents work with nutrients and fibers to form an integrated part of defense system against various diseases and stress conditions. The phytochemicals are grouped into two main categories (6) namely primary constituents which includes amino acids, common sugars, proteins and chlorophyll etc., and secondary constituents consisting of alkaloids, essential oils, flavonoids, tannins, terpenoids, saponins, phenolic compounds etc. $(7,8)$. Majority of phytochemicals have been known to bear valuable therapeutic activities such as insecticidals, antibacterial, antifungal, anti-constipative, spasmolytic, antiplasmodial and antioxidant activities etc. The plants thus find their medicinal value due to respective phytochemical constituents they contains (9-12).

Leaf is considered to be one of the highest accumulatory parts of the plant containing bioactive compounds which are synthesized as secondary metabolites (13). Due to the presence of various compounds that are essential for good health, it can also be used to improve the health status of society (14). The medicinal quality of plants depends on their chemical constituents that have physiological activity in human systems (15). Microorganisms that form a parasitic association with other organisms are classified as pathogens. Some bacteria and fungi can be pathogenic while some are not. The search for novel potent plants and plant components against pathogenic microorganisms has become increasingly important, as a result of the development of antibiotic resistance in microbes (16). Antimicrobial investigation of plant extracts and phytochemicals is the basis for antimicrobial drug discovery (17, 18).

So the objective of my study to evaluate the phytochemicals present in leaf extracts of selected medicinal plants.

\section{Materials and Methods:-}

Plant materials and Extraction:

Total six medicinal plants like Alternanthera ficoidea L., Mussaenda belilla L., Carica papaya L., Talinum fruticosum L., Kalanchoe pinnata L., and Eupatorium perfoliatum L., were collected from in and around the area of Mangalore and Belthangady (Dakshina Kannada, District). The plants were identified and authenticated by the botanist of Department of Applied Botany, Mangalore University. These leaf samples were separated from each plant and were washed with running tap water, surface sterilized in distilled water, blot it dried and powdered. Different solvents viz., aqueous, ethanol and methanol were used for the extraction of leaf materials. 150 grams of the samples were weighed and extraction was carried out using soxhlet apparatus. The extracts obtained from the solvents were concentrated using rotary vacuum evaporator and then dried. The yielded crude extracts were stored in a deep freezer at $-20^{\circ} \mathrm{C}$ for the futher study.

\section{Qualitative Phytochemical Tests:}

Phytochemical analysis was carried out for the plant extracts as per the standard methods (19).

\section{Test for carbohydrates}

Benedict's test: $5 \mathrm{ml}$ of Benedict's solution was added to $0.5 \mathrm{mg}$ of extract and boiled in water bath for 2 mins. The appearance of red or yellow or green precipitate indicates the presence of reducing sugars.

\section{Test for proteins}

Xanthoproteic test: $0.5 \mathrm{mg}$ extract was treated with few of drops of Conc. $\mathrm{HNO}_{3}$ formation of yellow indicates the presence of proteins.

Biuret test: To each $0.5 \mathrm{mg}$ of extract $2 \mathrm{ml}$ of Biuret reagent was added, production of violet colour indicates the presence of protein.

\section{Test for amino acids}

Ninhydrin test: About $0.5 \mathrm{mg}$ of extract was taken and 2 drops of freshly prepared $0.2 \%$ ninhydrin reagent was added and heated. The appearance of pink or purple colour indicates the presence of proteins, peptides or amino acids.

\section{Test for alkaloids}

Wagner's test: About $10 \mathrm{mg}$ of extract was taken and few drops of Wagner's reagent were added. The formation of a reddish brown precipitate indicates the presence of alkaloids. 


\section{Test for saponins}

Foam test: $0.5 \mathrm{mg}$ of extract was diluted with $20 \mathrm{ml}$ distilled water and shaken well in a graduated cylinder for 15 $\min$. The formation of foam to a length of $1 \mathrm{~cm}$ indicated the presence of saponins and steroids.

\section{Test for phenols}

Sodium hydroxide test: $0.5 \mathrm{mg}$ of extract was dissolved in $0.5 \mathrm{ml}$ of $20 \%$ sulphuric acid solution. Followed by addition of few drops of aqueous sodium hydroxide solution, it turns blue which indicates the presence of phenols.

\section{Test for phytosterols}

Salkowski's test: $0.5 \mathrm{mg}$ of extract was dissolved in $2 \mathrm{ml}$ of chloroform and equal volume of Conc. $\mathrm{H}_{2} \mathrm{SO}_{4}$ was added along the sides of the test tube. The upper layer turns red and lower layer turns yellow with green fluorescence, indicating the presence of the sterols compound in the extract.

\section{Test for flavonoids}

Shinoda Test: To $0.5 \mathrm{mg}$ of extract a pinch of magnesium turnings and 1-2 drops of conc. $\mathrm{HCl}$ acid was added. Formation of pink colour indicates the presence of flavonoids.

\section{Test for cardiac glycosides}

Glycoside test: $0.5 \mathrm{mg}$ of extract was dissolved in $1 \mathrm{ml}$ of water and then aqueous $\mathrm{NaOH}$ solution was added. Formation of yellow colour indicates the presence of glycosides.

\section{Test for terpenoids}

Salkowski reaction: $0.5 \mathrm{mg}$ of extract was treated with $1 \mathrm{ml}$ of chloroform $\left(\mathrm{CHCl}_{3}\right)$ and $2 \mathrm{ml}$ of $\mathrm{Conc}_{2} \mathrm{H}_{2} \mathrm{SO}_{4}$ to produce a layer. Formations of reddish- brown colour of the interphase suggest that the existence of terpenoids.

\section{Test for tannins}

Lead acetate test: $0.5 \mathrm{mg}$ of extract was taken and $0.5 \mathrm{ml}$ of $1 \%$ lead acetate solution was added and the formation of precipitate indicates the presence of tannins compounds.

\section{Results and Discussion:-}

Qualitative phytochemical analysis of selected medicinal plant leaf extracts showed the presence of carbohydrates, proteins, amino acids, alkaloids, saponins, phenols, phytosterols, tannins, quinines, glycosides, steroids, terpenoids and flavonoids. The results were represented in the table 1 and 2 . The presence of these bioactive compounds in these extracts encourages antioxidant, anti-inflammatory and antimicrobial studies. Since several phytoconstituents like flavanoids, tannins, saponins and polyphenols are effective antimicrobial substances against a wide range of microorganisms (20-22). The presence of these bioactive compounds in the leaf extracts encourages antioxidant studies (23).

Phytochemical investigation showed the presence of components which are familiar to express therapeutic effect including physiological activity (24). All the selected medicinal plant extracts which were screened for phytochemicals showed the presence of carbohydrate, proteins, alkaloids, saponins, flavonoids and tannins.

Phytosterols were not present in C. papaya and T. fruticosum leaf extracts. Glycoside content was not observed in the leaf extracts of $A$. ficoidea and $T$. fruticosum. Terpenoids content was absent in leaf extracts of M. bellila and $C$. papaya.

Plants rich in tannins have antibacterial potential due to their character that allows them to react with proteins to form stable water-soluble compounds, which kills bacteria by directly damaging their cell walls (25). Phytotherapeutically, tannins containing plants are used to treat nonspecific diarrhoea, inflammations of mouth, throat, and slightly injured skins (26). Previous reports showed that saponins have antibiotic properties and so help the body to fight against infections and microbial invasion (27). Another important action of saponins is their expectorant action through the stimulation of a reflex of the upper digestive tract. Flavonoids have been recognized to possess anti-allergic, anti-inflammatory, antiviral, antiproliferative, and anticarcinogenic activities (25).

The anti-allergic function of flavonoids is particularly advantageous since it may help in the treatment of immune system disorders that are responsible for $5-10 \%$ of recurrent miscarriages $(28,29)$. Since flavonoids prevent platelet stickiness (platelet aggregation), they are probably wonderful remedies for the treatment of all types of miscarriages 
$(30,31)$. Through this preventive function, flavonoids 'thin the blood' and thereby inhibit the clotting pathway. Alkaloids are the most efficient therapeutically significant plant substances. Pure isolated alkaloids and the synthetic derivatives are used as basic medicinal agents because of their analgesic properties. The alkaloids consist of quinine, which is anti-malarial (25). It is reported that several drugs have been obtained from alkaloid-containing plants because of its pharmacological importance although higher doses can be toxic (32). In the present study the results showed that all the selected medicinal plants are of great importance to health of individual and communities. The medicinal values of a plant lie in some chemical substances that produce a definite physiological action on the human body. Phytochemical analysis is of paramount importance in identifying a new source of therapeutically and industrially valuable compounds having medicinal plants have been chemically investigated.

Table 1:- Qualitative phytochemical analysis of leaf extracts of selected medicinal plants.

\begin{tabular}{|l|c|c|c|c|c|c|c|c|c|}
\hline \multirow{2}{*}{ Tests } & \multicolumn{3}{|c|}{ A. ficoidea } & \multicolumn{3}{c|}{ M. bellila } & \multicolumn{3}{c|}{ C. papaya } \\
\cline { 2 - 11 } & Aqueous & Ethaonl & Methanol & Aqueous & Ethaonl & Methanol & Aqueous & Ethaonl & Methanol \\
\hline Carbohydrate & + & + & + & + & + & + & + & + & + \\
\hline Protein & + & - & + & + & + & + & + & + & + \\
\hline Amino acids & + & + & + & + & + & + & - & - & + \\
\hline Alkaloids & + & + & + & + & + & + & + & + & + \\
\hline Saponins & + & + & + & + & + & + & + & + & + \\
\hline Phenols & + & + & + & + & - & + & + & + & + \\
\hline Phytosterols & + & - & + & + & + & + & - & - & - \\
\hline Flavonoids & + & + & + & - & - & + & + & + & + \\
\hline Glycosides & - & - & - & + & - & + & + & + & + \\
\hline Terpenoids & + & + & + & - & - & - & - & - & - \\
\hline Tannins & + & + & + & - & + & + & + & + & - \\
\hline
\end{tabular}

$$
\text { '+: Present, - ': Absent }
$$

Table 2:- Qualitative phytochemical analysis of leaf extracts of selected medicinal plants.

\begin{tabular}{|l|c|c|c|c|c|c|c|c|c|}
\hline \multirow{2}{*}{ Tests } & \multicolumn{3}{|c|}{ T. fruticosum } & \multicolumn{3}{c|}{ K. pinnata } & \multicolumn{3}{c|}{ E. perfoliatum } \\
\cline { 2 - 11 } & Aqueous & Ethaonl & Methanol & Aqueous & Ethaonl & Methanol & Aqueous & Ethaonl & Methanol \\
\hline Carbohydrate & + & + & + & + & + & + & + & + & + \\
\hline Protein & + & + & + & + & - & - & + & + & + \\
\hline Amino acids & + & - & + & + & - & + & + & + & + \\
\hline Alkaloids & + & - & + & + & + & + & + & + & + \\
\hline Saponins & + & - & + & + & + & + & + & + & + \\
\hline Phenols & + & + & + & + & + & + & + & + & + \\
\hline Phytosterols & - & - & - & + & - & + & + & + & + \\
\hline Flavonoids & + & + & + & + & + & + & + & + & + \\
\hline Glycosides & - & - & - & + & - & - & + & + & + \\
\hline Terpenoids & + & - & - & + & - & + & + & + & + \\
\hline Tannins & + & + & + & + & + & + & + & + & + \\
\hline
\end{tabular}

\section{'+': Present, - ': Absent}

\section{Conclusion:-}

In this study, different solvent extraction played important role in detection phytochemicals/bioactive compounds from different selected plant samples. Ethanol or water was not effective, whereas methanol solvents showed the presence of most of phytochemicals like phenolic, flavonoids, alkaloids and saponins which is responsible for high antioxidant properties in plant samples. Methanol can extract most of the compounds like in water or ethanol. But the compounds that are polar metabolites (flavonoids, phenolic compounds, alkaloids, etc) can be easily extracted through methanol. Depending on the nature of the metabolite that want to extract, methanol either pure or $70 \% / 30 \%$ solutions may be used, to optimise, according to tissue type, moisture status etc. Methanol is generally the best solvent for use with secondary metabolites (33). Therefore, methanol extract was used to evaluate the activity of medicinal plants.

\section{Declarations}




\section{Acknowledgements:-}

Thanks to Department of Biosciences, Mangalore University to carry out my research work.

\section{Authors' contributions}

Laveena K B designed the experiments and lab works were done by Laveena K B and tabulated the results. Authors have read and approved the final state of the manuscript.

\section{Funding}

No funding.

\section{Availability of data and materials}

Work was carried out by the corresponding author.

\section{Ethics approval}

No animal work.

\section{Consent for publication}

Not applicable

\section{Competing interests}

The authors declare that they have no competing interests.

\section{References:-}

1. Iwu, M.M.; Jackson, J.E.; Schuster, B.G. (1994). Medicinal plants in the fight against leishmaniasis. Parasitology Today, 10(2): 65-8.

2. Geedhu, D.; Krishnakumari, S.; (2015). Quantitative analysis of primary and secondary metabolites in aqueous hot extract of Eugenia uniflora L. leaves, Asian Journal of Pharmaceutical and Clinical Research, 8(1): 334-338.

3. Liu, R.H. (2004). Potential synergy of phytochemicals in cancer prevention: mechanism of Action. Journal of Nutrition, 134(12): 3479S-3485S.

4. Abo, K.A.; Ogunleye, V.O.; Ashidi, J.S. (1991). Antimicrobial potential of Spondias mombin, Croton zambesicus and Zygotritonia crocea. Phytotherapy Research, 5(13): 494-497.

5. Nweze, E.L.; Okafor, J.L.; Njoku, O. (2004). Antimicrobial activities of methanolic extracts of Trume guineesis (Scchumn and Thorn) and Morinda lucinda used in Nigerian herbal medicinal practice. Journal of Biological Research and Biotechnology, 2(1): 34-46.

6. Krishnaiah, D.; Devi, T.; Bono, A.; Sarbatly, R. (2009). Studies on phytochemical constituents of six Malaysian medicinal plants. Research Journal of Medicinal Plant, 3(2): 67-72.

7. Krishnaiah, D.; Sarbatly, R.; Bono, A. (2007). Phytochemical antioxidants for health and medicine - A move towards nature. Biotechnology and Molecular Biology Reviews, 1(4): 097-104.

8. Edeoga, H.O.; Okwu, D.; Mbaebie, B.O. (2005). Phytochemical constituents of some Nigerian medicinal plants. African Journal of Biotechnology, 4(7): 685-8.

9. Kambu, K.; Phenzu, D.; Coune, N.C.; Wauter, J.N.; Angenot, L. (1982). Plants. Medicine and Phytotherapy, 16: 34.

10. Lemos, T.L.; Matos, F.J.; Alencar, J.W.; Crareiro, A.A.; Clark, A.M.; Chesnary, J.D. (1990). Antimicrobial activity of essential oils of Brazilian plants. Phytotherapy Research, 4(2): 82-4.

11. Ferdous, A,J.; Islam, S.M.; Ahsan, M.; Hassan, C.M.; Ahmad, Z.V. (1992). In vitro antibacterial activity of the volatile oil of Nigella sativa seeds against multiple drug-resistant isolates of Shigella spp. and isolates of Vibrio cholerae and Escherichia coli. Phytotherapy Research, 6(3): 137-40.

12. Vardar-Unlu, G.; Candan, F.; Sokmen, A.; Daferera, D.; Polissiou, M.; Sokmen M. (2003). Antimicrobial and antioxidant activity of the essential oil and methanol extracts of Thymus pectinatus Fisch. et Mey. Var. pectinatus (Lamiaceae). Journal of Agriculture and Food Chemistry, 51: 63-67.

13. Cowan, M.M. (1999). Plant products as antimicrobial agents. Clinical Microbiology Reviews, 12(4): 564-582.

14. Farina Mujeeb.; Preeti Bajpai.; Neelam Pathak. (2014). Phytochemical Evaluation, Antimicrobial Activity, and Determination of Bioactive Components from Leaves of Aegle marmelos, Hindawi Publishing Corporation, BioMed Research International, 1-11. 
15. Kumar, A.; Rajput, G.; Dhatwalia, V.K. (2009). Phytocontent screening of Mucuna seeds and exploit in opposition to pathogenic microbes. Journal of Biological and Environmental Sciences, 3: 71-76.

16. Ahmad, I.; Aqil, F.; Owais, M. (2006). Modern phytomedicine: Turning medicinal plants into drugs, WileyVCH, India, pp. 404.

17. Cseke, L.J.; Kirakosyan, A.; Kaufman, P.B.; Warber, S.L.; Duke, J.A.; Brielmann, H.L.; (2006). Natural product from plants. CRC Press; Taylor and Francis Group, LLC, Boca Raton, Florida, United States of America, 2nd edn, 611.

18. Innocent Okeke, C.; Chinelo Ezeabara, A. (2018). Phytochemical screening and in vitro antimicrobial activity of various parts of Cleome ciliata Schum. \& Thonn. Bioscience Horizons, 11: 1-7.

19. Harborne, I.B. (1973). Phytochemical methods; A guide to modern techniques of plant analysis. 2nd Edition, Chapman and Hall, New York: 88-185.

20. Tsuchiya, H.; Sato, M.; Miyazaki, T.; Fujiwara, S.; Tanigaki, S.; Ohyama, M.; Tanaka, T.; Iinuma, M. (1996). Comparative study on the antibacterial activity of phytochemical flavanones against methicillin resistant Staphylococcus aureus. Journal of Ethnopharmacology, 50: 27-34.

21. Ya, C.; Gaffney, S.H.; Lilley, T.H.; Haslam, E. (1988). Carbohydrate-polyphenol complexation. In: Hemingway RW, Karchesy JJ (Edition), Chemistry and Significance of condensed tannins. Plenum Press, New York, pp. 553.

22. Nabila, B.; Mirici, S.; Duran, A. (2008). Antioxidant and antimicrobial activities of the Pistacia lentiscus and Pistacia atlantica extracts. International Journal of Pharmtech Research, 2(2): 2-28.

23. Laveena, K.B.; Chandra, M. (2018). Evaluation of bioactive compounds, antioxidant and antibacterial properties of medicinal plants Sauropus androgynus L. and Erythrina variegata L. Asian Journal of Pharmaceutical and clinical research, 11(12): 313-312.

24. Sofowora, A. (2013). Screening plants for bioactive agents in: Medicinal plants and traditional medicinal in Africa, 2nd Edition. Spectrum Books Ltd, Sunshine House, Ibadan: 191-289.

25. Baskaran, C.; Ratha, V.; Velu, S.; Kumaran, K. (2012). The efficacy of Carica papaya leaf extract on some bacterial and a fungal strain by well diffusion method. Asian Pacific Journal of Tropical Disease: 658-662.

26. Idris, S.; Ndukwe, G.; Gimba, C.E. (2009). Preliminary phytochemical screening and antimicrobial activity of seed extracts of Persea americana (avocado pear). Bayero Journal of Pure and Applied Sciences, 2(1): 173-176.

27. Charistima, Y.; Thiruvengadarajan, V.S. (2013). A review on identification strategy of phytoconstituent present in herbal plants. International Journal of Research in Pharmaceutical Science, 4(2): 123-140.

28. Akamene, F.I. (2008). Identification and preliminary phytochemical analysis of herbs that can arrest threatened miscarriage in Orba and Nsukka towns of Enugu State. African Journal of Biotechnology, 7(1): 6-11.

29. Mohapatra, S.P. (2011). Preliminary phytochemical analysis and conservation of herbs used by the tribal people of Bolangir (Orissa), India as a remedy against threatened miscarriage. Research in Pharmacy, 1(1): 33-40.

30. Njoku, V.; Obi, C.; Onyema, O.M. (2011). Phytochemical constituents of plants. African Journal of Biotechnology. 10(66): 15020-15024.

31. Ifeoma, F. (2008). Identification and preliminary phytochemical analysis of herbs that can arrest threatened miscarriage in Orba and Nsukka towns of Enugu State. African Journal of Biotechnology, 7(1): 6-11.

32. Li, N.; Xia, Q.; Ruan, J.; Fu, P.P.; Lin, G. (2011). Hepatotoxicity and tumorigenicity induced by metabolic activation of pyrrolizidine alkaloids in herbs. Current Drug Metabolism, 12(9): 823-834.

33. Thanh Van Ngo.; Christopher James Scarlett.; Michael Christian Bowyer.; Phuong Duc Ngo.; Quan Van Vuon. (2017). Impact of different extraction solvents on bioactive compounds and antioxidant capacity from the root of Salacia chinensis L. Journal of Food Quality: 1-8. 